\title{
REVIEW
}

\section{Alert to US physicians: DHEA, widely used as an OTC androgen supplement, may exacerbate COVID-19}

\author{
Jonathan Nyce \\ ACGT Biotechnology, Collegeville, Pennsylvania, USA \\ Correspondence should be addressed to J Nyce: professor@acgt.us
}

\begin{abstract}
Androgens play a fundamental role in the morbidity and mortality of COVID-19, inducing both the ACE-2 receptor to which SARS-CoV-2 binds to gain entry into the cell, and TMPRS22, the transmembrane protease that primes the viral spike protein for efficient infection. The United States stands alone among developed nations in permitting one androgen, oral DHEA, to be freely available OTC and online as a 'dietary supplement'. DHEA is widely used by males in the US to offset the age-related decline in circulating androgens. This fact may contribute to the disparate statistics of COVID-19 morbidity and mortality in this country. In regulatory antithesis, every other developed nation regulates DHEA as a controlled substance. DHEA is an extremely potent inhibitor of glucose-6phosphate dehydrogenase (G6PD), with uniquely unstable uncompetitive inhibition kinetics. This has particular relevance to COVID-19 because G6PD-deficient human cells have been demonstrated to be exceptionally sensitive to infection by human coronavirus. Because DHEA is lipophilic and freely passes into cells, oral DHEA bypasses the normal controls regulating androgen biology and uncompetitive G6PD inhibition. DHEA's status as a 'dietary supplement' means that no clinical trials demonstrating safety have been performed, and, in the absence of physician supervision, no data on adverse events have been collected. During the current pandemic, the unrestricted availability of oral DHEA as a 'dietary supplement' cannot be considered safe without proof from placebo-controlled clinical trials that it is not contributing to the severity of COVID-19. US physicians may therefore wish to query their patients' use of DHEA.
\end{abstract}

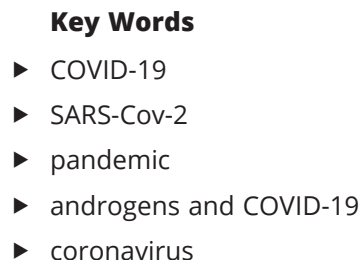

Endocrine-Related Cancer (2020) 28, R47-R53

\section{Introduction}

COVID-19 is an acute disease that primarily targets the respiratory system, but with increasing evidence of involvement of additional organ systems. Severe acute respiratory syndrome coronavirus-2 (SARS-CoV-2), the etiologic agent of COVID-19, uses its spike protein to bind ACE2 receptors as an entry point into the cell. ACE 2 receptors are present on the surface of type 1 and type 2 pulmonary epithelial cells, but are also present on other cell types, including endothelial cells in vascular tissues throughout the body (Berger 2020, DiNicolantonio \& McCarty 2020, Evans et al. 2020, Panfoli 2020). Infection with SARS-CoV-2 in humans is associated with systemic inflammatory reactions, most notably in the lung (Stawicki et al. 2020), but also in the digestive tract (Aktas \& Aslim 2020, Effenberger et al. 2020, Garland et al. 2020, Hanrahan et al. 2020, Villapol 2020); 
kidney (Joseph et al. 2020, Lv et al. 2020); brain (Najjar et al. 2020, Vargas et al. 2020); liver (Garland et al. 2020); skin (Gisondi et al. 2020) - most likely via endothelial damage to cutaneous blood vessels (Garduño-Soto \& Choreño-Parra 2020) - and heart (Basu-Ray et al. 2020, Grimaud et al. 2020, Kochi et al. 2020, Tahir et al. 2020, Zou et al. 2020). Reports suggest that SARS-CoV-2-associated vascular endothelialitis may underlie the inflammatory reactions occurring in this spectrum of organ systems (Ackermann et al. 2020, Evans et al. 2020).

\section{The role of androgens in the morbidity and mortality of COVID-19}

Males are affected more severely by COVID-19 than are females, suggesting that androgens may underlie this gender-related difference in morbidity and mortality (Bhowmick et al. 2020, Papadopoulos et al. 2020, Sharifi \& Ryan 2020, Wambier \& Goren 2020, Wambier et al. 2020). Indeed, treatment of prostate cancer patients with antiandrogen therapy has been reported to exert a protective effect against infection by SARS-CoV-2 (Bahmad \& AbouKheir 2020, Montopoli et al. 2020), and women with polycystic ovarian syndrome, a condition characterized by hyperandrogenism (Yang et al. 2019), have been reported to be a potential exception to the rule that females are more resistant to the effects of SARS-CoV-2 infection than are males (Kyrou et al. 2020, Moin et al. 2020). Androgenic alopecia is prevalent in men hospitalized for COVID-19 (Goren et al. 2020, Lee et al. 2020), and the increased prevalence of prostate cancer and androgenic alopecia among African Americans correlates with the frequency of particular variants in the androgen receptor (McCoy et al. 2020).

Androgens upregulate both the ACE-2 receptor to which SARS-CoV-2 binds to gain entry into the cell (Samuel et al. 2020), and the protease TMPRSS2 (type II transmembrane serine protease-2) (Clinckemalie et al. 2013, Lucas et al. 2014), which facilitates virus-host cell fusion by priming the SARS-CoV-2 spike protein, thereby increasing susceptibility to SARS-CoV-2 infection and development of severe COVID-19 (Dong et al. 2020, Ragia \& Manolopoulos 2020, Stopsack et al. 2020, Strope et al. 2020). Activated androgen receptor upregulates TMPRSS2 mRNA (Wambier et al. 2020), while androgen deprivation therapy suppresses it (Bhowmick et al. 2020, Mjaess et al. 2020). In vitro elimination of TMPRSS2 activity using a protease inhibitor blocks the ability of SARS-CoV-2 to infect human cells (Hoffmann et al. 2020). The low morbidity and mortality of SARS-CoV-2 infection in very young children correlates with their pre-adrenarche developmental stage (see subsequently) (Mihalopoulos et al. 2020).

\section{The unrestricted availability of DHEA subverts normal androgen controls that have evolved in primates, including humans}

The androgen DHEA is regulated as a controlled substance in virtually every developed country in the world, with the singular exception of the United States. Until 1994, DHEA was also regulated as a controlled substance in the U.S., in the same manner as other androgens. Any proposed use required placebo-controlled, double-blind clinical trials to demonstrate safety. This changed with the passage into law of the 'Dietary Supplement Health and Education Act of 1994'. This Act exempted DHEA from clinical trials to demonstrate safety, an exemption that was based on a 'presumption' of safety founded entirely upon its apparent lack of toxicity in mice and rats. But humans and other primates evolved completely different androgen biology than mice and rats - biology based upon extraordinarily high levels of circulating DHEAS, and extraordinarily low levels of DHEA in the blood (five orders of magnitude lower than for DHEAS). Despite the lack of safety studies in humans, DHEA is widely available online and at retail establishments such as pharmacies and supermarkets, in dosage forms ranging up to $100 \mathrm{mg}$ per capsule. It is estimated that ingestion of a single $100 \mathrm{mg}$ capsule is sufficient to raise the average person's blood levels to the supraphysiologic range. Based upon its highly touted but unproven - anti-aging effects, DHEA is widely used in the US, particularly by men, in the belief that its ingestion will offset, without ill effects, the decline in DHEAS that occurs as a function of aging. But as illustrated in the graphical abstract, DHEAS and DHEA have completely different biological activities, blood concentrations, and toxicities (Fig. 1).

Primates are unique among mammals in having evolved an adrenal gland capable of synthesizing and secreting DHEA sulfate (DHEAS), and humans are unique among primates in having by far the highest levels of circulating DHEAS, and in completely separating adrenarche from gonadarche as a distinct developmental stage. At human adrenarche, maturation of the zona reticularis converts the adrenal gland into a DHEASsecreting organ.

Blood levels of this androgen peak at age 25 to about $3200 \mathrm{ng} / \mathrm{mL}$ in males, and $2000 \mathrm{ng} / \mathrm{mL}$ in females, 


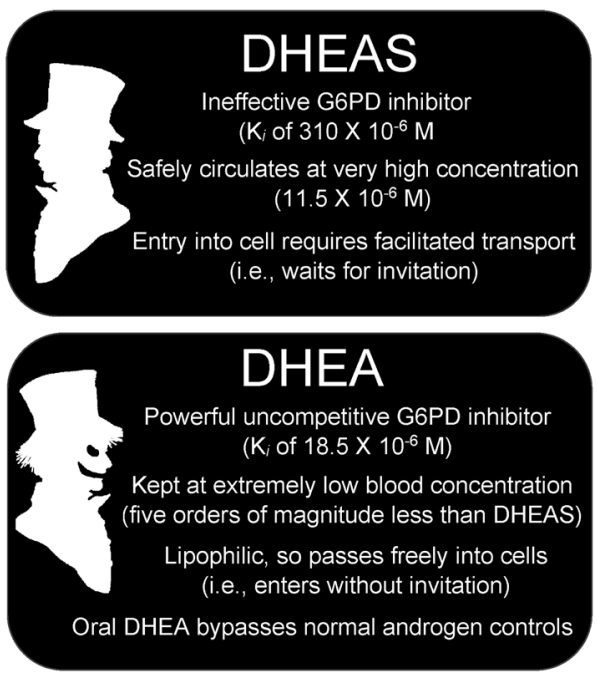

Figure 1

DHEAS and DHEA are the Dr Jekyll and Mr Hyde of androgen biology.

gradually declining thereafter. Circulating DHEAS can be converted intracellularly to DHEA, a potent uncompetitive inhibitor of glucose-6-phosphate dehydrogenase (G6PD). Uncompetitive inhibition is otherwise unknown in natural systems because, in the presence of high levels of inhibitor and substrate, it rapidly becomes irreversible (CornishBowden 1986). As Cornish-Bowden has pointed out, 'any metabolic pathway in which uncompetitive inhibition can occur can potentially respond catastrophically to the presence of inhibitor'. G6PD is the main source for the synthesis of NADPH required for selenoprotein synthesis, a group of proteins most of which act as oxidoreductases to detoxify reactive oxygen species (ROS) (Zhang et al. 2020); and for FSP1-mediated reduction of ubiquinone to ubiquinol, required for the prevention of ironmediated ferroptosis (Dixon et al. 2012). Uncompetitive inhibition of G6PD by DHEA thus has the potential to induce ROS/ferroptosis-mediated cell death, and this has been proposed as the basic element of a primate-specific, 'kill switch' tumor suppression mechanism (Nyce 2018, 2019, 2020). DHEA'a ability to powerfully inhibit G6PD has special relevance to the COVID-19 pandemic because reduction in normal G6PD activity has been shown to sensitize human cells to coronavirus infection ( $\mathrm{Wu}$ et al. 2008).

Normal human physiology has evolved a three-part safety mechanism that prevents uncompetitive inhibition of G6PD from becoming unleashed in normal cells. First and foremost, blood levels of DHEA are kept extremely low, five orders of magnitude lower than for DHEAS. Second, DHEAS cannot enter cells without transport facilitated by organic anion transport protein (OATP). And third, DHEAS requires subsequent de-sulfation by steroid sulfatase (SS) before it becomes the uncompetitive G6PD inhibitor DHEA. Unlike hydrophilic DHEAS, lipophilic DHEA freely diffuses across cell membranes. Oral DHEA thus bypasses this three-part safety mechanism that evolved to protect normal cells from uncompetitive inhibition of G6PD (Fig. 2).

The effect of long-term exposure of humans to doses of oral DHEA that raise serum concentrations to levels above the physiologic range has not been studied. In dogs, such dosing can cause a systemic inflammatory reaction that does not occur in mice or rats (Nyce 2017a), a finding that might be explained by the fact that the canine adrenal gland more closely models the human that is, unlike murine species, DHEAS is primarily secreted by the adrenal gland in female dogs (Mongillo et al. 2014). There is additional evidence from studies in canines that endothelial tissues are particularly sensitive to the effects of oral DHEA, possibly due to the tissue-specific expression of endothelial nitric oxide synthase (eNOS) (Nyce 2017b). To produce nitric oxide (NO) and maintain vascular tone, eNOS must remain 'coupled', which means that the NADPH-dependent production of tetrahydrobiopterin (BH4) - a critical cofactor for eNOS activity - must be maintained. In endothelial cells in which uncompetitive inhibition of G6PD by oral DHEA has led to the depletion of intracellular NADPH, and loss of NADPH has depleted BH4, eNOS becomes 'uncoupled', and instead of NO, the highly reactive peroxide, peroxynitrate, is formed instead (Radi 2018). As with ROS, several selenoproteins - which

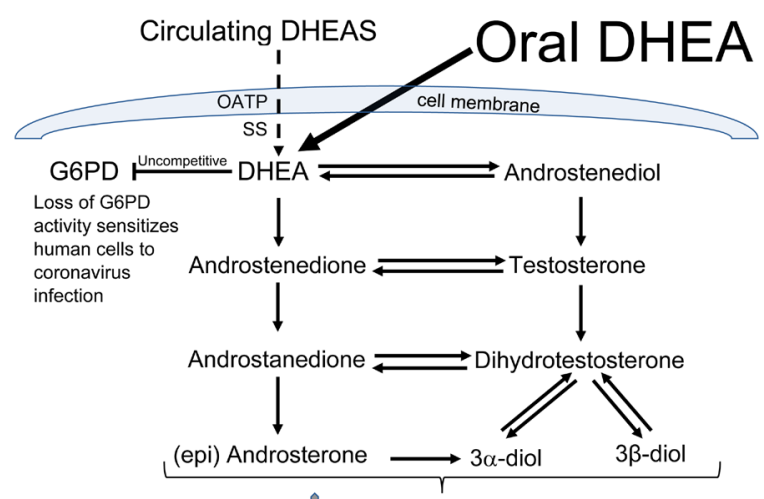

Androgens induce both ACE2 $\bigwedge$, the cell surface receptor to which SARS-CoV-2 binds; and TMPRS22 3 , the transmembrane protease that primes the viral spike protein for efficient infection ( * o

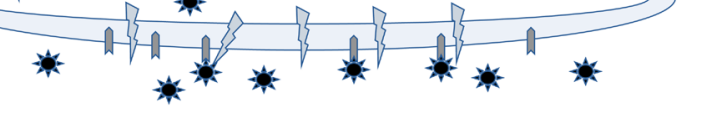

\section{Figure 2}

Oral DHEA subverts the controls that have evolved in human androgen biology, and may exacerbate COVID-19 by facilitating viral entry, and by precipitating vascular endothelialitis. OATP, organic anion transport protein; SS, steroid sulfatase. 
are also dependent upon NADPH for their synthesis - are required for peroxynitrate detoxification. If this finding of endothelial hypersensitivity to DHEA translates from dogs to humans, men consuming oral DHEA might increase endothelial peroxynitrate levels via enos uncoupling, simultaneously with a reduction in the ability of those endothelial cells to synthesize protective selenoproteins. Elevation of circulating DHEA levels much beyond its normal ultralow blood level of $18.5 \mathrm{nM}$ may thus be particularly toxic to endothelial cells, which have a low threshold for interference with their redox controls. In subjects with SARS-Cov-2 infection, supraphysiologic serum concentrations of DHEA may enhance or precipitate the vascular endothelialitis observed with such infection (Ackermann et al. 2020, Evans et al. 2020).

\section{The compounding effects of diabetes and G6PD deficiency upon androgen-enhanced COVID-19 morbidity and mortality}

Taken together, these facts suggest that DHEA may potentiate SARS-CoV-2-induced vascular endothelialitis, contributing to multi-organ inflammatory reactions. This effect may be further magnified in diabetic patients, since G6PD activity is already significantly reduced in them (Heymann et al. 2012, Mahmoud \& Nor El-Din 2013), lowering the threshold at which DHEA could induce ROS/peroxynitrate-mediated endothelial cell death and ensuing vascular endothelialitis. Poor glycemic control observed in many diabetic patients could further compound the effects of DHEA, since it would elevate G6P levels, the G6PD substrate required for uncompetitive inhibition of G6PD to become irreversible. Diabetes with poor glycemic control has reached epidemic proportions in both the Hispanic (Loganathan et al. 2017, AguayoMazzucato et al. 2019) and African American (Marshall 2005) communities, which both have experienced disproportionately high levels of COVID-19 morbidity and mortality (Moore et al. 2020).

G6PD deficiency, the most common inherited genetic disease, would also lower the threshold at which DHEAinduced, ROS/RNS-mediated vascular endothelialitis could occur. It has already been demonstrated in ex vivo studies that G6PD-deficient cells are more vulnerable to human coronavirus infection than are G6PD normal cells (Wu et al. 2008) - which is also further evidence that self-administration of the uncompetitive G6PD inhibitor DHEA will increase vulnerability to SARS-CoV-2 infection.
African Americans and people of Hispanic origin, who endure increased morbidity and mortality from COVID-19, are disproportionately affected by both G6PD deficiency and diabetes (Carter et al. 1996, Levine et al. 2001, Wong et al. 2002), albeit the latter due primarily to socioeconomic status rather than genetic factors (Signorello et al. 2007). G6PD deficiency and diabetes are linked in additional ways. Thus, levels of glycated hemoglobin, HbA1c, are used to diagnose type 2 diabetes. A recent study demonstrated that the common G6PD variant rs1050828 is associated with lower HbA1c in African Americans, and that 650,000 African Americans with diabetes will remain undiagnosed when screened by HBA1c if this G6PD genetic information is not taken into account (Wheeler et al. 2017). A similar situation appears to occur in people of Hispanic origin, and in American Indians (Moon et al. 2019). Persons of Middle Eastern descent are also at higher risk for G6PD deficiency than other groups. G6PD deficiency is also more common among males than females, since it is an X-linked recessive hereditary disease. Finally, ketosis-prone diabetes, which predominantly occurs in males of West African descent, shows a high prevalence of G6PD deficiency without G6PD mutation (Sobngwi et al. 2005). This relatively occult form of diabetes/G6PD deficiency could therefore also potentiate the effects of DHEA consumption in African Americans with SARS-Cov-2 infection. The bottom line is that both diabetes and G6PD deficiency, maladies particularly afflicting the African American community, intersect as variables that could potentiate androgen enhancement of SARS-CoV-2 driven vascular endothelialitis.

\section{Conclusion}

DHEA's status as a 'dietary supplement' - a status for this androgen that is unique to the US - means that no clinical trials demonstrating safety have been performed, and, in the absence of physician supervision, no data on adverse events have been or are being collected. This is particularly troubling in the era of COVID-19, the severity of which is known to be associated with androgen exposure. The unrestricted consumption of DHEA as a 'dietary supplement' in the US may therefore represent an unappreciated risk factor for the development of severe forms of COVID-19. DHEA's uncompetitive mechanism of inhibition of G6PD - remarkable for its unstable kinetics, which can rapidly become 'catastrophic' in the presence of (c) 2021 Society for Endocrinology Published by Bioscientifica Ltd. Printed in Great Britain 
increasing intracellular concentrations of G6P (such as occur in diabetes) - should be a red flag that self-dosing in the absence of physician supervision is contraindicated during the COVID-19 pandemic; particularly in subjects in whom diabetes and/or G6PD deficiency are present as co-morbidities. It would therefore seem prudent for regulatory authorities to consider suspending OTC availability of oral DHEA unless it can be proven in placebo-controlled, randomized, double-blind clinical trials that it is not contributing to the morbidity and mortality of COVID-19 in the United States. To avoid or to determine the etiology of - inflammatory reactions occurring in COVID-19 patients, physicians in the US may wish to query use or abuse of DHEA in their workup of patient histories, and more routinely request lab analyses of DHEA (not DHEAS) serum levels.

\section{Declaration of interest}

The author declares that there is no conflict of interest that could be perceived as prejudicing the impartiality of this review.

\section{Funding}

This work was supported by a grant from the De Cicco Foundation.

\section{References}

Ackermann M, Verleden SE, Kuehnel M, Haverich A, Welte T, Laenger F, Vanstapel A, Werlein C, Stark H, Tzankov A, et al. 2020 Pulmonary vascular endothelialitis, thrombosis, and angiogenesis in Covid-19. New England Journal of Medicine 383 120-128. (https://doi. org/10.1056/NEJMoa2015432)

Aguayo-Mazzucato C, Diaque P, Hernandez S, Rosas S, Kostic A \& Caballero AE 2019 Understanding the growing epidemic of type 2 diabetes in the Hispanic population living in the United States. Diabetes/Metabolism Research and Reviews 35 e3097. (https://doi. org/10.1002/dmrr.3097)

Aktas B \& Aslim B 2020 Gut-lung axis and dysbiosis in COVID-19. Turkish Journal of Biology 44 265-272. (https://doi.org/10.3906/biy2005-102)

Bahmad HF \& Abou-Kheir W 2020 Crosstalk between COVID-19 and prostate cancer. Prostate Cancer and Prostatic Diseases 23 561-563. (https://doi.org/10.1038/s41391-020-0262-y)

Basu-Ray I, Almaddah NK, Adeboye A \& Soos MP 2020 Cardiac manifestations of coronavirus (COVID-19). In StatPearls. StatPearls Publishing. (available at: https://www.ncbi.nlm.nih.gov/books/ NBK556152/)

Berger JR 2020 COVID-19 and the nervous system. Journal of NeuroVirology 26 143-148. (https://doi.org/10.1007/s13365-02000840-5)

Bhowmick NA, Oft J, Dorff T, Pal S, Agarwal N, Figlin RA, Posadas EM, Freedland SJ \& Gong J 2020 COVID-19 and androgen-targeted therapy for prostate cancer patients. Endocrine-Related Cancer $\mathbf{2 7}$ R281-R292. (https://doi.org/10.1530/ERC-20-0165)
Carter JS, Pugh JA \& Monterrosa A 1996 Non-insulin-dependent diabetes mellitus in minorities in the United States. Annals of Internal Medicine 125 221-232. (https://doi.org/10.7326/0003-4819-125-3199608010-00011)

Clinckemalie L, Spans L, Dubois V, Laurent M, Helsen C, Joniau S \& Claessens F 2013 Androgen regulation of the TMPRSS2 gene and the effect of a SNP in an androgen response element. Molecular Endocrinology 27 2028-2040. (https://doi.org/10.1210/me.20131098)

Cornish-Bowden A 1986 Why is uncompetitive inhibition so rare? A possible explanation, with implications for the design of drugs and pesticides. FEBS Letters 203 3-6. (https://doi.org/10.1016/00145793(86)81424-7)

DiNicolantonio JJ \& McCarty M 2020 Thrombotic complications of COVID-19 may reflect an upregulation of endothelial tissue factor expression that is contingent on activation of endosomal NADPH oxidase. Open Heart 7 e001337. (https://doi.org/10.1136/ openhrt-2020-001337)

Dixon SJ, Lemberg KM, Lamprecht MR, Skouta R, Zaitsev EM, Gleason CE, Patel DN, Bauer AJ, Cantley AM, Yang WS, et al. 2012 Ferroptosis: an iron-dependent form of nonapoptotic cell death. Cell 149 1060-1072. (https://doi.org/10.1016/j.cell.2012.03.042)

Dong M, Zhang J, Ma X, Tan J, Chen L, Liu S, Xin Y \& Zhuang L 2020 ACE2, TMPRSS2 distribution and extrapulmonary organ injury in patients with COVID-19. Biomedicine and Pharmacotherapy 131 110678. (https://doi.org/10.1016/j.biopha.2020.110678)

Effenberger M, Grabherr F, Mayr L, Schwaerzler J, Nairz M, Seifert M, Hilbe R, Seiwald S, Scholl-Buergi S, Fritsche G, et al. 2020 Faecal calprotectin indicates intestinal inflammation in COVID-19. Gut 69 1543-1544. (https://doi.org/10.1136/gutjnl-2020-321388)

Evans PC, Rainger G, Mason JC, Guzik TJ, Osto E, Stamataki Z, Neil D, Hoefer IE, Fragiadaki M, Waltenberger J, et al. 2020 Endothelial dysfunction in COVID-19: a position paper of the ESC Working Group for Atherosclerosis and Vascular Biology, and the ESC Council of Basic Cardiovascular Science. Cardiovascular Research 116 cvaa230. (https://doi.org/10.1093/cvr/cvaa230)

Garduño-Soto M \& Choreño-Parra JA 2020 Cutaneous susceptibility to SARS-CoV-2 infection according to the expression of viral entry factors in the skin. Gaceta medica de Mexico 156 354-357. (https:// doi.org/10.24875/GMM.20000308)

Garland V, Kumar AB \& Borum ML 2020 Gastrointestinal and hepatic manifestations of COVID-19: evolving recognition and need for increased understanding in vulnerable populations. Journal of the National Medical Association [epub]. (https://doi.org/10.1016/j. jnma.2020.07.017)

Gisondi P, Piaserico S, Conti A Naldi L, Bordin C, Alaibac M, Girolomoni 2020. Cutaneous manifestations of SARS-CoV-2 infection: a clinical update. Journal of the European Academy of Dermatology and Venereology 34 1196-1201. (https://doi. org $/ 10.1111 / j d v .16774)$

Goren A, Vaño-Galván S, Wambier CG, McCoy J, Gomez-Zubiaur A, Moreno-Arrones OM, Shapiro J, Sinclair RD, Gold MH, Kovacevic M, et al. 2020 A preliminary observation: male pattern hair loss among hospitalized COVID-19 patients in Spain - a potential clue to the role of androgens in COVID-19 severity. Journal of Cosmetic Dermatology 19 1545-1547. (https://doi.org/10.1111/jocd.13443)

Grimaud M, Starck J, Levy M, Marais C, Chareyre J, Khraiche D, LeruezVille M, Quartier P, Léger PL, Geslain G, et al. 2020 Acute myocarditis and multisystem inflammatory emerging disease following SARS-CoV-2 infection in critically ill children. Annals of Intensive Care 10 69. (https://doi.org/10.1186/s13613-020-00690-8)

Hanrahan TP, Lubel JS \& Garg M 2020 Lessons from COVID-19, ACE2, and intestinal inflammation: could a virus trigger chronic intestinal inflammation? Clinical Gastroenterology and Hepatology S15423565(20)30998-8. (https://doi.org/10.1016/j.cgh.2020.07.036) (c) 2021 Society for Endocrinology Published by Bioscientifica Ltd. Printed in Great Britain 
Heymann AD, Cohen Y \& Chodick G 2012 Glucose-6-phosphate dehydrogenase deficiency and type 2 diabetes. Diabetes Care 35 e58. (https://doi.org/10.2337/dc11-2527)

Hoffmann M, Kleine-Weber H, Schroeder S, Krüger N, Herrler T, Erichsen S, Schiergens TS, Herrler G, Wu NH, Nitsche A, et al. 2020 SARS-CoV-2 cell entry depends on ACE2 and TMPRSS2 and is blocked by a clinically proven protease inhibitor. Cell 181271. e8-280.e8. (https://doi.org/10.1016/j.cell.2020.02.052)

Joseph A, Zafrani L, Mabrouki A, Azoulay E \& Darmon M 2020 Acute kidney injury in patients with SARS-CoV-2 infection. Annals of Intensive Care 10 117. (https://doi.org/10.1186/s13613-020-00734-z)

Kochi AN, Tagliari AP, Forleo GB, Fassini GM \& Tondo C 2020 Cardiac and arrhythmic complications in patients with COVID-19. Journal of Cardiovascular Electrophysiology 31 1003-1008. (https://doi. org/10.1111/jce.14479)

Kyrou I, Karteris E, Robbins T, Chatha K, Drenos F \& Randeva HS 2020 Polycystic ovary syndrome (PCOS) and COVID-19: an overlooked female patient population at potentially higher risk during the COVID-19 pandemic. BMC Medicine 18 220. (https://doi. org/10.1186/s12916-020-01697-5)

Lee J, Yousaf A, Fang W, \& Kolodney MS 2020 Male balding is a major risk factor for severe COVID-19. Journal of the American Academy of Dermatology 83, e353-e354. (https://doi.org/10.1016/j. jaad.2020.07.062)

Levine RS, Foster JE, Fullilove RE, Fullilove MT, Briggs NC, Hull PC, Husaini BA \& Hennekens CH 2001 Black-white inequalities in mortality and life expectancy, 1933-1999: implications for healthy people 2010. Public Health Reports 116 474-483. (https://doi. org/10.1093/phr/116.5.474)

Loganathan S, Green M, Hasche J, Koenig K \& Guerino P 2017 Racial and Ethnic Disparities in Diabetes Prevalence, Self-Management, and Health Outcomes among Medicare Beneficiaries. CMS Office of Minority, Health Centers for Medicare \& Medicaid Services. (available at: https://www.cms.gov/About-CMS/Agency-Information/OMH/ research-and-data/information-products/data-highlights/disparitiesin-diabetes-prevalence) 6

Lucas JM, Heinlein C, Kim T, Hernandez SA, Malik MS, True LD, Morrissey C, Corey E, Montgomery B, Mostaghel E, et al. 2014 The androgen-regulated protease TMPRSS2 activates a proteolytic cascade involving components of the tumor microenvironment and promotes prostate cancer metastasis. Cancer Discovery 4 1310-1325. (https://doi.org/10.1158/2159-8290.CD-13-1010)

Lv W, Wu M, Ren Y, Zeng N, Deng P, Zeng H, Zhang Q \& Wu Y 2020 Coronavirus disease 2019: coronaviruses and kidney injury. Journal of Urology 204 918-925. (https://doi.org/10.1097/JU.0000000000001289)

Mahmoud AA \& Nor El-Din AK 2013 Glucose-6-phosphate dehydrogenase activity and protein oxidative modification in patients with type 2 diabetes mellitus. Journal of Biomarkers 2013 430813. (https://doi.org/10.1155/2013/430813)

Marshall Jr MC2005 Diabetes in African Americans. Postgraduate Medical Journal 81 734-740. (https://doi.org/10.1136/pgmj.2004.028274)

McCoy J, Wambier CG, Vano-Galvan S, Shapiro J, Sinclair R, Ramos PM, Washenik K, Andrade M, Herrera S \& Goren A 2020 Racial variations in COVID-19 deaths may be due to androgen receptor genetic variants associated with prostate cancer and androgenetic alopecia. Are anti-androgens a potential treatment for COVID-19? Journal of Cosmetic Dermatology 19 1542-1543. (https://doi.org/10.1111/ jocd.13455)

Mihalopoulos M, Levine AC, Marayati NF, Chubak BM, Archer M, Badani KK, Tewari AK, Mohamed N, Ferrer F \& Kyprianou N 2020 The resilient child: sex-steroid hormones and COVID-19 incidence in pediatric patients. Journal of the Endocrine Society 4 bvaa106. (https://doi.org/10.1210/jendso/bvaa106)

Mjaess G, Karam A, Aoun F, Albisinni S \& Roumeguère T 2020 COVID19 and the male susceptibility: the role of ACE2, TMPRSS2 and the androgen receptor. Progres en Urologie 30 484-487. (https://doi. org/10.1016/j.purol.2020.05.007)

Moin ASM, Sathyapalan T, Atkin SL \& Butler AE 2020 Renin-angiotensin system overactivation in polycystic ovary syndrome, a risk for SARSCoV-2 infection? Metabolism Open 7 100052. (https://doi. org/10.1016/j.metop.2020.100052)

Mongillo P, Prana E, Gabai G, Bertotto D \& Marinelli L 2014 Effect of age and sex on plasma cortisol and dehydroepiandrosterone concentrations in the dog (Canis familiaris). Research in Veterinary Science 96 33-38. (https://doi.org/10.1016/j.rvsc.2013.10.010)

Montopoli M, Zumerle S, Vettor R, Rugge M, Zorzi M, Catapano CV, Carbone GM, Cavalli A, Pagano F, Ragazzi E, et al. 2020 Androgendeprivation therapies for prostate cancer and risk of infection by SARS-CoV-2: a population-based study $(\mathrm{N}=4532)$. Annals of Oncology 31 1040-1045 (https://doi.org/10.1016/j. annonc.2020.04.479)

Moon JY, Louie TL, Jain D, Sofer T, Schurmann C, Below JE, Lai CQ, Aviles-Santa ML, Talavera GA, Smith CE, et al. 2019 A genome-wide association study identifies blood disorder-related variants influencing hemoglobin $\mathrm{A}_{1 \mathrm{c}}$ with implications for glycemic status in U.S. Hispanics/latinos. Diabetes Care 42 1784-1791. (https://doi. org/10.2337/dc19-0168)

Moore JT, Ricaldi JN, Rose CE, Fuld J, Parise M, Kang GJ, Driscoll AK, Norris T, Wilson N, Rainisch G, et al. 2020 Disparities in incidence of COVID-19 among underrepresented racial/ethnic groups in counties identified as hotspots during June 5-18, 2020 - 22 States, February-June 2020. Morbidity and Mortality Weekly Report 69 1122-1126. (https://doi.org/10.15585/mmwr.mm6933e1)

Najjar S, Najjar A, Chong DJ, Pramanik BK, Kirsch C, Kuzniecky RI, Pacia SV \& Azhar S 2020 Central nervous system complications associated with SARS-CoV-2 infection: integrative concepts of pathophysiology and case reports. Journal of Neuroinflammation $\mathbf{1 7}$ 231. (https://doi.org/10.1186/s12974-020-01896-0)

Nyce JW 2017a Autoinflammatory reaction in dogs treated for cancer via G6PD inhibition. Case Reports in Veterinary Medicine $\mathbf{2 0 1 7}$ 4275305. (https://doi.org/10.1155/2017/4275305)

Nyce JW $2017 b$ Species specificity of an adrenal androgen-mediated killswitch triggered by p53 inactivation. Translational Medicine Reports 2 76-85. (https://doi.org/10.4081/tmr.6773)

Nyce JW 2018 Detection of a novel, primate-specific 'kill switch' tumor suppression mechanism that may fundamentally control cancer risk in humans: an unexpected twist in the basic biology of TP53. EndocrineRelated Cancer 25 R497-R517. (https://doi.org/10.1530/ERC-18-0241)

Nyce JW 2019 Species-specific mechanisms of tumor suppression are fundamental drivers of vertebrate speciation: critical implications for the 'war on cancer'. Endocrine-Related Cancer 26 C1-C5. (https://doi. org/10.1530/ERC-18-0468)

Nyce JW 2020 A lex naturalis delineates components of a humanspecific, adrenal androgen-dependent, p53-mediated 'kill switch' tumor suppression mechanism. Endocrine-Related Cancer 27 R51-R65. (https://doi.org/10.1530/ERC-19-0382)

Panfoli I 2020 Potential role of endothelial cell surface ectopic redox complexes in COVID-19 disease pathogenesis. Clinical Medicine 20 e146-e147. (https://doi.org/10.7861/clinmed.2020-0252)

Papadopoulos V, Li L \& Samplaski M 2020 Why does COVID-19 kill more elderly men than women? Is there a role for testosterone? Andrology [epub]. (https://doi.org/10.1111/andr.12868)

Radi R 2018 Oxygen radicals, nitric oxide, and peroxynitrite: redox pathways in molecular medicine. PNAS 115 5839-5848. (https://doi. org/10.1073/pnas.1804932115)

Ragia G \& Manolopoulos VG 2020 Inhibition of SARS-CoV-2 entry through the ACE2/TMPRSS2 pathway: a promising approach for uncovering early COVID-19 drug therapies. European Journal of Clinical Pharmacology 76 1623-1630. (https://doi.org/10.1007/ s00228-020-02963-4) (c) 2021 Society for Endocrinology Published by Bioscientifica Ltd. Printed in Great Britain 
Samuel RM, Majd H, Richter MN, Ghazizadeh Z, Zekavat SM, Navickas A, Ramirez JT, Asgharian H, Simoneau CR, Bonser LR, et al. 2020 Androgen regulates SARS-CoV-2 receptor levels and is associated with severe COVID-19 symptoms in men. Cell Stem Cell 27 876-889. (https://doi.org/10.1016/j.stem.2020.11.009)

Sharifi N \& Ryan CJ 2020 Androgen hazards with COVID-19. Endocrine-Related Cancer 27 E1-E3. (https://doi.org/10.1530/ ERC-20-0133)

Signorello LB, Schlundt DG, Cohen SS, Steinwandel MD, Buchowski MS, McLaughlin JK, Hargreaves MK \&Blot WJ 2007 Comparing diabetes prevalence between African Americans and Whites of similar socioeconomic status. American Journal of Public Health $\mathbf{9 7}$ 2260-2267. (https://doi.org/10.2105/AJPH.2006.094482)

Sobngwi E, Gautier JF, Kevorkian JP, Villette JM, Riveline JP, Zhang S, Vexiau P, Leal SM, Vaisse C \& Mauvais-Jarvis F 2005 High prevalence of glucose-6-phosphate dehydrogenase deficiency without gene mutation suggests a novel genetic mechanism predisposing to ketosis-prone diabetes. Journal of Clinical Endocrinology and Metabolism 90 4446-4451. (https://doi.org/10.1210/jc.2004-2545)

Stawicki SP, Jeanmonod R, Miller AC, Paladino L, Gaieski DF, Yaffee AQ De Wulf A, Grover J, Papadimos TJ, Bloem C, et al. 2020 The 20192020 novel coronavirus (severe acute respiratory syndrome coronavirus 2) pandemic: a joint American College of Academic International Medicine-World Academic Council of Emergency Medicine Multidisciplinary COVID-19 Working Group Consensus Paper. Journal of Global Infectious Diseases 12 47-93. (https://doi. org/10.4103/jgid.jgid_86_20)

Stopsack KH, Mucci LA, Antonarakis ES, Nelson PS \& Kantoff PW 2020 TMPRSS2 and COVID-19: serendipity or opportunity for intervention? Cancer Discovery 10 779-782. (https://doi. org/10.1158/2159-8290.CD-20-0451)

Strope JD, PharmD C, PharmD CHC \& Figg WD 2020 TMPRSS2: potential biomarker for COVID-19 outcomes. Journal of Clinical Pharmacology 60 801-807. (https://doi.org/10.1002/jcph.1641)

Tahir F, Bin Arif T, Ahmed J, Malik F \& Khalid M 2020 Cardiac manifestations of coronavirus disease 2019 (COVID-19): a comprehensive review. Cureus 12 e8021. (https://doi.org/10.7759/ cureus.8021)

Vargas G, Medeiros Geraldo LH, Gedeão Salomão N, Viana Paes M, Regina Souza Lima F \& Carvalho Alcantara Gomes F 2020 Severe acute respiratory syndrome coronavirus 2 (SARS-CoV-2) and glial cells: insights and perspectives. Brain, Behavior, and Immunity: Health 7 100127. (https://doi.org/10.1016/j.bbih.2020.100127)
Villapol S 2020 Gastrointestinal symptoms associated with COVID-19: impact on the gut microbiome. Translational Research 226 57-69. (https://doi.org/10.1016/j.trsl.2020.08.004)

Wambier CG \& Goren A 2020 Severe acute respiratory syndrome coronavirus 2 (SARS-CoV-2) infection is likely to be androgen mediated. Journal of the American Academy of Dermatology $\mathbf{8 3}$ 308-309. (https://doi.org/10.1016/j.jaad.2020.04.032)

Wambier CG, Goren A, Vaño-Galván S, Ramos PM, Ossimetha A, Nau G, Herrera S \& McCoy J 2020 Androgen sensitivity gateway to COVID19 disease severity. Drug Development Research 81 771-776. (https:// doi.org/10.1002/ddr.21688)

Wambier CG, Vaño-Galván S, McCoy J, Gomez-Zubiaur A, Herrera S, Hermosa-Gelbard Á, Moreno-Arrones OM, Jiménez-Gómez N, González-Cantero A, Fonda-Pascual P, et al. 2020 Androgenetic alopecia present in the majority of patients hospitalized with COVID-19: the 'Gabrin sign'. Journal of the American Academy of Dermatology 83 680-682. (https://doi.org/10.1016/j. jaad.2020.05.079)

Wheeler E, Leong A, Liu CT, Hivert MF, Strawbridge RJ, Podmore C, Li M, Yao J, Sim X, Hong J, et al. 2017 Impact of common genetic determinants of hemoglobin A1c on type 2 diabetes risk and diagnosis in ancestrally diverse populations: a transethnic genomewide meta-analysis. PLoS Medicine 14 e1002383. (https://doi. org/10.1371/journal.pmed.1002383)

Wong MD, Shapiro MF, Boscardin WJ \& Ettner SL 2002 Contribution of major diseases to disparities in mortality. New England Journal of Medicine 347 1585-1592. (https://doi.org/10.1056/NEJMsa012979)

Wu YH, Tseng CP, Cheng ML, Ho HY, Shih SR \& Chiu DT 2008 Glucose6-phosphate dehydrogenase deficiency enhances human coronavirus 229E infection. Journal of Infectious Diseases 197 812-816. (https:// doi.org/10.1086/528377)

Yang Q, Mao Q, Liu M, Wang K, Wu Z, Fang W, Yang Z, Luo P, Ke S \& Shi L 2016 The inhibitory effect of dehydroepiandrosterone and its derivatives against influenza $\mathrm{A}$ virus in vitro and in vivo. Archives of Virology 161 3061-3072. (https://doi.org/10.1007/s00705016-2993-6)

Zhang Y, Roh YJ, Han SJ, Park I, Lee HM, Ok YS, Lee BC \& Lee SR 2020 Role of selenoproteins in redox regulation of signaling and the antioxidant system: a review. Antioxidants 9 383. (https://doi. org/10.3390/antiox9050383)

Zou F, Qian Z, Wang Y, Zhao Y \& Bai J 2020 Cardiac injury and COVID19: a systematic review and meta-analysis. CJC Open 2 386-394. (https://doi.org/10.1016/j.cjco.2020.06.010)

Received in final form 27 October 2020

Accepted 23 November 2020

Accepted Manuscript published online 27 November 2020 (c) 2021 Society for Endocrinology Published by Bioscientifica Ltd. Printed in Great Britain 